\title{
Status of glucose metabolism including insulin resistance and beta cell function in overtly iron loaded Thalassemia patients
}

\section{Pan $\mathrm{A}^{1}$, Nag SS${ }^{2}$, Mondal $\mathrm{BC}^{2}$, Anindya Dasgupta $\mathrm{A},{ }^{3}$ Piyali Mitra $\mathrm{P}^{4}$}

${ }^{1}$ College of Medical Sciences Department of Paediatrics,Bharatpur,Nepal, ${ }^{2}$ Department of Pediatrics, ${ }^{3}$ Department of Biochemistry and ${ }^{4}$ Department of Pathology, Burdwan Medical College, Burdwan, India.

\begin{abstract}
\section{BACKGROUND}

Abnormality of glucose metabolism is a frequent complication in Thalassemia patients. Both insulin deficiency and insulin resistance has been proposed in its pathogenesis. Some form of abnormality in glucose metabolism is expected at an earlier age in these patients in developing countries like India and Nepal where iron overload is excessive due to lack of chelation therapy.
\end{abstract}

\section{MATERIALS AND METHODS}

Fasting serum glucose and fasting serum insulin (FSI) were measured in 40 beta-thalassemia major patients, 40 Ebeta- thalassemia patients and 40 controls, all aged between 5 and 12 years. 2 hours after an appropriate dose of oral glucose feed (Children ingested $1.75 \mathrm{~g} / \mathrm{kg}$ body weight maximum 75 gram dissolved in 250 to $300 \mathrm{ml}$ water) blood samples were drawn again to measure post prandial serum glucose. Iron overload was assessed by measuring liver size, spleen size, total amount of packed cells transfused and serum ferritin. Insulin resistance (IR), insulin sensitivity (\%S) and beta cell functions $(\% \mathrm{~B})$ were derived from the measured laboratory parameters using the latest version of Homeostatic Model Assessment(HOMA) calculator software.

\section{RESULTS}

No one had impaired glucose metabolism or diabetes mellitus beta-thalassemia major patients showed evidence of insulin resistance in the form of significantly higher fasting serum insulin ( $p$ value 0.002), IR ( $p$ value 0.003 ), \%B ( $p$ value 0.017 ) and significantly lower \%S (0.002) when compared with controls. FSI showed positive correlation with total amount of packed cells received ( $r=0.372, p=0.018)$, serum ferritin $(r=0.345, p=0.029)$ and spleen size $(r=0.427, p=0.006)$. Similarly, IR also showed positive correlation with total amount of packed cells received $(r=0.388, p=0.013)$, serum ferritin $(r=0.336, p=0.034)$ and spleen size $(r=0.425, p=0.005)$. \%S showed negative correlation with all these parameters. \%B didn't show any statistically significant correlation with these parameters. Ebeta- thalassemia patients didn't have any statistically significant difference in FSI, IR, \%S and \%B than controls.

\section{CONCLUSION}

Insulin resistance develops as the earliest abnormality in glucose metabolism in overtly iron loaded beta thalassemia major patients at an early age. Ebeta- thalassemia patients with milder phenotype do not develop dysfunction of glucose metabolism at such an early age.

Key words : Glucose metabolism, Insulin resistance, Insulin sensitivity, Beta cell function,beta- thalassemia major, Ebeta- thalassemia.

Correspondence: Dr. Atanu Pan

E-mail: atanu8k@yahoo.co.uk 


\section{INTRODUCTION}

The thalassemias are a heterogenous group of singlegene disorder characterized by reduced rate of production of normal haemoglobin due to absent or reduced synthesis of one or more types of globin polypeptide chains resulting in chronic haemolytic anaemia. Blood transfusion is the mainstay of care of individuals with thalassemia which improves anemia and suppresses ineffective erythropoiesis. Regular transfusions have prolonged and improved quality of life of patients with this disease. ${ }^{1,2}$ However, in absence of iron chelation therapy, blood transfusions increase iron overload. It is pronounced if transfusions are not optimum and regular due to GDF-15 (secreted from enormously expanded and active bone marrow) mediated increase in iron absorption. So, blood transfusions, whether adequate or inadequate, leads to iron overload in various organs like heart, liver, pituitary, thyroid, parathyroid, pancreas etc. Sixty percent of thalassemic patients have hypofunction of at least one endocrine gland. ${ }^{3}$ Disturbances of glucose metabolism are frequent in these patients. However, there is no consensus regarding etiology of abnormal glucose metabolism. Though insulin deficiency has been proposed as the causative factor, some studies report presence of insulin resistance and hyperinsulinemia. Evidence of insulin resistance has also been noted in thalassemics without any abnormality in serum glucose. ${ }^{4}$

In India and Nepal, chelation is suboptimal in most of the patients due to economic constraints. Even compliance to transfusion is often not optimal. ${ }^{5}$ Therefore, there is a possibility that our patients may develop some form of derangement in glucose metabolism at an earlier age.E beta thalassemia is a common variety of thalassemia found in Eastern part of India, besides beta- thalassemia major; but no study is available regarding glucose metabolism status in them.Keeping these in mind, we planned our study to evaluate the status of glucose metabolism in terms of incidence of diabetes, impaired glucose tolerance and parameters related to insulin resistance in thalassemia patients (both beta thalassemia major and $\mathrm{E}$ beta thalassemia) who do not receive chelation therapy.

\section{MATERIALS \& METHODS}

Thalassemia patients attending Burdwan Medical College and Hospital and College of Medical Sciences Bharatpur for treatment were included in this study. They were divided into two groups - beta thalassemia major and $\mathrm{E}$ beta thalassemia; 40 patients from each group were selected. Patients aged between 5 and 12 years, diagnosed by electrophoresis or High Performance Liquid Chromatography, were included in the study. Exclusion criteria were: patients receiving chelation therapy, patients infected with Hepatitis B and $C$ viruses and patients whose $1^{\text {st }}$ degree relatives (non-thalassemic) and who were suffering from diabetes. 40 beta- thalassemia major patients (group 1) and 40 E-beta thalassemia patients (group 2) who satisfied these criteria were selected for the study. We also involved 40 controls (group 3), who were selected randomly from healthy siblings of patients (nonthalassemic) attending Pediatric Out Patient Department for minor ailments. The study was conducted after obtaining informed consent from parents of cases and controls and permission from institutional ethical committee. Following an overnight fasting for 8 hours, a venous blood sample was collected next day to estimate fasting plasma glucose, fasting serum insulin and serum ferritin. Then the patients were given a feed of glucose solution using dose of 
1.75 gm glucose per kg body weight. After 2 hours, another blood sample was collected for post prandial plasma glucose estimation. Blood glucose level was assayed by Glucose oxidase- Peroxidase (GODPOD) method, serum insulin and serum ferritin by Non Competitive ELISA method. Insulin resistance (IR), insulin sensitivity $(\% \mathrm{~S})$ and beta cell functions $(\% \mathrm{~B})$ were derived from the measured laboratory parameters using the latest versionof HOMA calculator software.In our study, we have used the HOMA Calculator 2.2.2 software developed by Oxford University. Finally, all the data were analysed using SPSS software version 17.0.

\section{RESULTS}

In our study no one from any group had qualified to be labeled as suffering from diabetes mellitus (DM) or having impaired glucose tolerance.

Fasting serum insulin, insulin resistance and beta cell function $(\% \mathrm{~B})$ all were significantly higher in group 1 , when compared to group 2 and group 3. Insulin sensitivity $(\% \mathrm{~S})$ was significantly lower in group 1 , compared to other groups. No significant difference was noted between groups 2 and 3 in any of these parameters [Table 1].

\section{Table 1: Demographic, clinical and biochemical parameters among various groups}

\begin{tabular}{|c|c|c|c|c|c|c|}
\hline \multirow[t]{2}{*}{ Parameters } & \multicolumn{3}{|c|}{ Mean \pm SD } & \multicolumn{3}{|c|}{$\mathrm{p}$ values } \\
\hline & $\begin{array}{c}\text { Group 1 } \\
\beta \text { thal. major }\end{array}$ & $\begin{array}{c}\text { Group } 2 \\
\mathrm{E} \beta \text { thalassemia }\end{array}$ & $\begin{array}{l}\text { Group } 3 \\
\text { Control }\end{array}$ & $\mathrm{p}_{1-2}$ & $\mathrm{p}_{1-3}$ & $\mathrm{p}_{2-3}$ \\
\hline Liver Size(cm) & $6.78 \pm 2.02$ & $2.61 \pm 1.07$ & & $<0.001$ & & \\
\hline Spleen Size $(\mathrm{cm})$ & $10.60 \pm 3.81$ & $5.64 \pm 1.27$ & & $<0.001$ & & \\
\hline $\mathrm{FBS}(\mathrm{mg} / \mathrm{dl})$ & $89.35 \pm 5.71$ & $87.72 \pm 5.62$ & $88.27 \pm 5.31$ & 0.204 & 0.386 & 0.654 \\
\hline PPBS(mg/dl) & $118.10 \pm 7.06$ & $116.73 \pm 6.14$ & $115.97 \pm 5.15$ & 0.356 & 0.128 & 0.556 \\
\hline $\mathrm{SFI}(\mathrm{ng} / \mathrm{ml})$ & $9.25 \pm 1.64$ & $8.09 \pm 0.71$ & $8.24 \pm 1.07$ & $<0.001$ & 0.002 & 0.494 \\
\hline IR & $1.19 \pm 0.22$ & $1.05 \pm 0.09$ & $1.07 \pm 0.16$ & $<0.001$ & 0.003 & 0.449 \\
\hline$\% \mathrm{~S}$ & $86.02 \pm 13.84$ & $96.58 \pm 8.29$ & $95.69 \pm 12.89$ & $<0.001$ & 0.002 & 0.713 \\
\hline$\% \mathrm{~B}$ & $109.61 \pm 14.57$ & $104.88 \pm 13.64$ & $101.32 \pm 15.95$ & 0.137 & 0.017 & 0.287 \\
\hline Serum ferritin & $4360.00 \pm 1705.01$ & $2036.77 \pm 415.84$ & $68.97 \pm 15.04$ & $<0.001$ & $<0.001$ & $<0.001$ \\
\hline
\end{tabular}

$\mathrm{p}_{1-2}$ is $\mathrm{p}$ value when groups 1 and 2 are compared for significance, $\mathrm{p}_{1-3}$ between groups 1 and 3 and $p_{2-3}$ between groups 2 and 3 . 
In group 1, FSI and IR showed positive correlation with some parameters related to iron overload like total amount of packed cells received, serum ferritin and spleen size. $\% \mathrm{~S}$ showed negative correlation with these parameters. $\% \mathrm{~B}$, though, was significantly higher among patients of group 1 ; it didnot show any correlation with these parameters [Table 2].

Table 2: Correlation of FSI, IR, \%S and \%B with various clinical and biochemical parameters among patients of beta thalassemia major

\begin{tabular}{|c|c|c|c|c|c|}
\hline \multicolumn{2}{|c|}{} & $\begin{array}{c}\text { Total amount of } \\
\text { packed cells received }\end{array}$ & liver size & spleen size & serum ferritin \\
\hline \multirow{2}{*}{ FSI } & $\mathrm{r}$ & 0.372 & 0.237 & 0.427 & 0.345 \\
\cline { 2 - 6 } & $\mathrm{p}$ & 0.018 & 0.140 & 0.006 & 0.029 \\
\hline \multirow{2}{*}{ IR } & $\mathrm{r}$ & 0.388 & 0.248 & 0.425 & 0.336 \\
\cline { 2 - 6 } & $\mathrm{p}$ & 0.013 & 0.123 & 0.006 & 0.034 \\
\hline \multirow{2}{*}{$\% \mathrm{~S}$} & $\mathrm{r}$ & -0.421 & -0.287 & -0.465 & -0.392 \\
\cline { 2 - 7 } & $\mathrm{p}$ & 0.007 & 0.073 & 0.002 & 0.012 \\
\hline & $\mathrm{r}$ & -0.127 & -0.019 & -0.052 & 0.009 \\
\hline
\end{tabular}

\section{DISCUSSION}

Result of our study reflects the ground reality of condition of most of the thalassemic patients in developing countries including ours where iron chelation therapy is suboptimal or not done at all. Regular blood transfusion is also not done in some cases. This is reflected by very high serum ferritin levels in them.

In our study no one among the cases or controls had Diabetes Mellitus(DM) or Impaired Glucose Tolerance(IGT). The reported incidence of impaired glucose tolerance and diabetes mellitus vary from 0 $19.5 \%$ (4-11) to $0-24 \%$ respectively in different studies. ${ }^{4-5,7-11}$ Though diabetes has been observed as early as 5.5 years $^{5}$, but mean age of onset of DM and IGT is late adolescence onwards, as found in different studies. ${ }^{9,12}$ Findings of various studies are given in Table
3.We worked with thalassemic patients with lower age group of 5 to 12 years. These patients, if followed up, might eventually turn out to have deranged glucose metabolism. Apart from iron overload, development of impaired glucose metabolism is also influenced by various other factors. Viral hepatitis affects glucose metabolism in these patients in various ways. Diabetes has been precipitated shortly after an episode of acute viral hepatitis in these patients. ${ }^{13}$ Chronic viral hepatitis has a diabetogenic effect. ${ }^{14}$ Some workers have found that iron induced hepatic damage is accentuated by $\mathrm{HCV}$ infection. ${ }^{15}$ Hepatic cirrhosis is another liver related condition implicated as causal factor. ${ }^{14}$ Besides these, other factors postulated include pancreatic autoimmunity demonstrated by islet cell antibodies, ${ }^{16}$ possible genetic factors ${ }^{9}$ and family history of diabetes. ${ }^{17}$ In this study, our aim was to ascertain the sole effect of 
iron overload. So, we excluded these confounding factors as much as possible during selection of cases as per inclusion and exclusion criteria. This may be another reason why we did not find any case with impaired glucose metabolism. A study from India did not find any case with DM or IGT in the age group of 8 to 15 years. ${ }^{4}$ This similarity in result may be due to common genetic factors in this region of world which needs further exploration. The conventional method of detecting glucose metabolism abnormalities is glucose tolerance test. Recently, Soliman AT et al ${ }^{18}$ used Continuous Glucose Monitoring System and found it to be more sensitive in detecting such abnormalities.

Though we could not detect DM or IGT among our patients, evidence of insulin resistance was detected in the form of higher FSI and IR in patients with beta thalassemia major, when compared with controls. Cario $\mathrm{H}$ et al ${ }^{19}$ found that patients with impaired glucose tolerance had hyperinsulinemia and delayed peak insulin during glucose tolerance test. Hafez $\mathrm{Met}^{2}{ }^{20} \mathrm{did}$ not mention on fasting plasma insulin levels but found mean postprandial insulin to be significantly higher ( $<<0.0001)$ in cases with impaired glucose metabolism. Higher fasting plasma insulin levels were also detected in the study by Suverna $\mathrm{J}$ et $\mathrm{al}^{4}$ among beta thalassemia major patients having no derangement in glucose metabolism. Some other studies also demonstrated increased insulin level following oral glucose or intravenous tolbutamide administration. Dmochowski $\mathrm{K}$ et $\mathrm{al}^{21}$ progressively analysed seven thalassemic patients with decreased insulin sensitivity and found that the insulin sensitivity remained the same but the integrated insulin response decreased. So they postulated that insulin resistance persists but at the same time a progressive reduction in circulatory insulin level occur which ultimately lead to diabetes. So, it appears that insulin resistance develops before any derangements in glucose level appear. This raised insulin level helps to counteract insulin resistance and maintain glucose homeostasis. With continuation of disease process, pancreatic beta cell damage starts leading to lowering of insulin level and increase in glucose level. Dmochowski K et $\mathrm{al}^{21}$ postulated that decreased hepatic uptake of insulin is the major factor for developing insulin resistance. Presence of insulin resistance has been shown also by Hafez $\mathrm{M}$ et al ${ }^{10}$ and Pappas $\mathrm{S}$ et $\mathrm{al}^{18}$.However, insulin resistance has not been found in some studies.

In our study, FSI and IR correlated with parameters related to iron overload like total amount of packed cells received, serum ferritin and spleen size revealing role of iron overload as risk factors for development of insulin resistance.

In our study, insulin Sensitivity in cases was found to be significantly lower than the controls ( $p$ value 0.001 ) by independent $t$ test. Some workers have found similar results ${ }^{19,21} . \%$ S correlates negatively with total amount of packed cells received, spleen size and serum ferritin. As we know insulin sensitivity is the reverse of insulin resistance, this finding is expected.

On the other hand, we found beta cell function to be significantly higher in cases than controls. There is dearth of literature regarding beta cell function. Jaruratanasirikul $\mathrm{S}$ et $\mathrm{al}^{12}$ showed a higher but not significant beta cell function index in patients with a normal glucose tolerance test than those with an abnormal glucose metabolism having liver and pancreatic cell damage. Suverna $\mathrm{J}$ et $\mathrm{al}^{4}$ found Beta cell function Index to be higher in cases as compared to controls but was not statistically significant $(p=0.077)$. However, to the contrary of our findings, Hafez $\mathrm{M}$ et $\mathrm{al}^{20}$ found significantly lower mean HOMA beta cell function 
$(\mathrm{p}=0.007)$ among cases than controls. The present study not only rules out hyposecretion of insulin in our patients, but may also indicate beta cell hyperfunction to explain rise of insulin level in the face of insulin resistance. Over time, further iron overload may increase insulin resistance and may also initiate damage to pancreatic beta cells with subsequent hyposecretion of insulin to give the full picture of impaired glucose metabolism. Unlike pancreas, liver is rich in reticuloendothelial cells where iron is stored. This might explain earlier liver damage and appearance of insulin resistance than hyposecretion of insulin.

FSI, IR, \%S, \%B was found to be significantly lower among EBT patients compared to BTM. It is known that EBT is a very heterogenous disease with variable clinical manifestations ranging from mild thalassemia intermedia with little or no symptoms to a very severe transfusion dependent thalassemia major syndrome. Our pool of E beta thalassemia patients have milder phenotype reflected by low transfusion requirement and not very high serum ferritin. So they are not overtly loaded with iron yet. This may be the reason that they do not show any statistically significant difference in terms of insulin related parameters when compared with control group.

Our beta thalassemia major patients showed evidence of insulin resistance but did not have overt impaired glucose tolerance or diabetes mellitus in spite of being heavily iron overloaded. From our study, it is evident that insulin resistance develops as the earliest abnormality in glucose metabolism in beta thalassemia major patients. Iron overload plays a significant role in its development. These patients should be monitored periodically to assess status of glucose metabolism. E beta thalassemia patients, who form a significant part of thalassemics in eastern part of India, have milder clinical manifestation reflected by low transfusion requirement and low serum ferritin. This group of patients does not show any evidence of insulin resistance or abnormality in serum glucose level. Chelation therapy should be started in all thalassemia patients so that iron overload related problems can be retarded.

\section{Table 3: Findings of some of the related studies}

\begin{tabular}{|l|c|c|c|c|c|c|c|}
\hline Study & $\begin{array}{c}\text { Study } \\
\text { group(yrs) }\end{array}$ & $\begin{array}{c}\text { Sample } \\
\text { size }\end{array}$ & Ferritin & $\begin{array}{c}\text { Patients with } \\
\text { IGM }\end{array}$ & $\begin{array}{c}\text { IGM } \\
\text { onset(yrs) }\end{array}$ & IR & Reference \\
\hline Present study & $5-12$ & 4 & $4360 \pm 1705$ & 0 & - & present & - \\
\hline Suverna J et al & $8-15$ & 30 & $7623 \pm 2381$ & 0 & - & present & 4 \\
\hline Gulati R et al & $3-22$ & 37 & $4920 \pm 2758$ & 3 & $5.5-18$ & - & 5 \\
\hline Jaruratanasirikul S et al & $13.6 \pm 3.9$ & 48 & $5206 \pm 3291$ & 6 & 11 to? & - & 12 \\
\hline Chern JPS et al & $2-36$ & 89 & $3107.3 \pm 2530.7$ & 23 & $7-27$ & - & 11 \\
\hline Khalifa AS et al & $10-31$ & 56 & $3648 \pm 2219$ & 12 & $18.33^{¥}$ & & 9 \\
\hline Arrigo T et al & $17-42$ & 29 & - & 4 & $18^{\epsilon}$ & absent & 10 \\
\hline Soliman TA et al & $14-22$ & 16 & - & 5 & - & absent & 18 \\
\hline
\end{tabular}

*12 patients were identified having IGM using continuous glucose monitoring system in the same study group. Insulin resistance found in 3(out of 16) patients. ${ }^{¥}$ indicates mean age. ${ }^{€}$ indicates lowest age of onset. 
Original Article

\section{CONTRIBUTIONS}

Dr Atanu Pan and Dr Badal Chandra Mandal conceptualized the study and reviewed the manuscript critically. AP and SSN collected the data, searched literature and drafted the manuscript. AD and PM helped in performing the investigations, searching the literature and also reviewed the manuscript.

\section{ACKNOWLEDGEMENT}

The authors are grateful to Kaustav Nayek, Associate Professor, Department of Pediatrics, Burdwan Medical College for his inputs during conceptualization of the study. The authors are also thankful to the institutional ethical committee for granting permission to carry out and publish the result of the study.

\section{REFERENCES}

1. Pignati CB, Rugolotto S, De Stefano P,Piga A, et al. Survival and disease complications in thalassemia major. Ann N Y Acad Sci 1998; 30(850):227-31.

2. Olivieri N, Koren G. survival in medically treated patients with homozygous thalassemia. New Eng J Med 1994; 331(9):574-8.

3. Aydinok Y, Darcan S, Polat A, et al. endocrine complications in patients with beta thalassemia major. $\mathrm{J}$ Trop Pediatr 2002;48:50-4.

4. Suvarna J, Ingle H, Deshmukh CT. Insulin resistance and beta cell function in chronically transfused patients of thalassemia major. Indian paediatr 2006; 43(5):313400 .

5. Gulati R, Bhatia V, Agarwal SS. Early onset of endocrine abnormalities in beta-thalassemia major in a developing country. J Pediatr Endocrinol Metab. 2000 Jun;13(6):651-6
6. Italian Working Group on Endocrine Complications in Non-endocrine Diseases. Multicentre study on prevalence of endocrine complications in Thalassaemia major. Clin Endocrinol 1995; 42: 581-6.

7. Flynn DM, Fairney A, Jackson D, et al. Hormonal changes in Thalassaemia major. Arch Dis Child 1976; 51: 828-36.

8. El-Hazmi MA, Al-Swailem A, Al-Fawaz I,et al. Diabetes mellitus in children suffering from beta-Thalassaemia. $\mathbf{J}$ Trop Pediatr 1994;40:261-6.

9. Khalifa AS, Salem M, Mounir E, et al. Abnormal glucose tolerance in Egyptian Beta thalassemic patients: Possible association in genotyping. Pediatr Diabetes 2004; 5: 12632.

10. Arrigo T, Crisafulli G, Meo A, et al. Glucose tolerance, insulin secretion and peripheral sensitivity in Thalassaemia major. J Pediatr Endocrinol Metab. 1998;11 Supp1 3: 863-6.

11. Chern JPS, Lin KH, Lu MY, et al. Abnormal glucose tolerance in transfusion dependent beta thalassemic patients.Diabetes Care 2001;24(5):850-4.

12. Jaruratanasirikul $\mathrm{S}$, Chareonmuang $\mathrm{R}$, Wongcharnchailert M, et al. Prevalence of impaired glucose metabolism in beta-thalassemic children receivinghypertransfusions with a suboptimal dosage of iron-chelating therapy. Eur J Pediatr 2008; 167:873-6.

13. De Sanctis V, Zurlo MG, Senesi E,et al. Insulin dependent diabetes in thalassemia. Arch Dis Child 1988; 63:58-62,

14. Labropoulou-Karatza C, Goritsas C, Fragopanagou H,et al: High prevalence of diabetes mellitus among adult bthalassemic patients with chronic hepatitis C. Eur JGastroenteol Hepatol 1999; 11:1033-6.

15. Piperno A, Fargion S, D'Alba R, et al. Liver damage in Italian patients with hereditary hemochromatosis is highly influenced by hepatitis B and C virus infection. $J$ Hepatol 1992; 16:364-8. 
16. Monge L, Pinach S, Caramellino L,et al. The possible role of autoimmunity in the pathogenesis of diabetes in beta-thalassemia major. Diabetes Metab 2001; 27:149-54.

17. Saudek CD, Hemm RM, Peterson CM. Abnormal glucose tolerance in beta Thalassaemiamajor. Metabolism 1977; 26:43-52.

18. Soliman AT, Yasin M, El-Awwa A,et al.Detection of glycemic abnormalities inadolescents with beta thalassemia usingcontinuous glucose monitoring and oral glucosetolerance in adolescents and young adults with beta thalassemia major: Pilot study. Indian J Endocr Metab 2013;17:490-5.
19. Cario H, Holl RW, Debatin KM,et al. Insulin sensitivity and beta-cell secretion in thalassaemia major with secondary haemochromatosis: assessment by oral glucose tolerance test. Eur J Pediatr 2003; 162: 139-46.

20. Hafez M, Youssry I, El-Hamed FA,et al. Abnormal glucose tolerance in beta-thalasemia: assessment of risk factors.Hemoglobin 2009; 33(2):101-8.

21. Dmochowski K, Finegood DT, Francombe W, et al. Factors determining glucose tolerance in patients with thalassemia major. J Clin Endocrinol Metab 1993; 77 : 478-83. 